\title{
PENGARUH BERMAIN PERAN TERHADAP KECERDASAN INTERPERSONAL PADA ANAK KELAS A DI TK BUAH HATI KOTA MAKASSAR
}

\author{
Muhammad Yusri Bachtiar \\ Univerisitas Negeri Makassar \\ Email: muh.yusri.b@gmail.com
}

\section{Artikel Diterima: 12 Juli 2017 Proses Review Artikel: 02 Agustus 2017}

Artikel Diterbitkan: 30 September 2017

\begin{abstract}
ABSTRAK
Permasalahan dalam penelitian adalah kurang berkembangnya kecerdasan interpersonal pada anak kelas B di Taman Kanak-Kanak Buah Hati Kota Makassar, sehingga peneliti memberikan perlakuan bermain peran untuk melihat apakah bermain peran dapat memberikan pengaruh terhadap kecerdasan interpersonal pada anak atau sebaliknya.Rumusah masalah penelitian ini adalah 1. Bagaimana gambaran kecerdasan interpersonal anak pada Taman Kanak-Kanak Buah Hati Makassar sebelum dan setelah diberikan perlakuan bermain peran ? 2. Apakah terdapat pengaruh bermain peran terhadap kecerdasan interpersonal pada anak ?.Berdasarkan hasil tersebut, penelitian ini bertujuan untuk 1.Menggambarkan kecerdasan interpersonal anak pada Taman Kanak-Kanak Buah Hati Makassar sebelum dan sesudah diberikan perlakuan bermain peran. 2. Mengetahui pengaruh bermain peran terhadap kecerdasan interpersonal pada anak. Pendekatan penelitian yang digunakan adalah kuantitatif.Jenis penelitian yang digunakan adalah Pra-Eksperimen.Desain penelitian adalah one group pretest-posttest.Sampel penelitian adalah seluruh anak kelompok B di Taman Kanak-Kanak Buah Hati Kota Makassar.Teknik pengumpulan data melalui teknik observasi dan dokumentasi.Teknik analisis data yang digunakan adalah statistik deskriftif dan statistik nonparametrik. Nilai kecerdasan interpersonal anak sebelum diberikan perlakuan memiliki rata-rata sebesar 22,6 dan setelah diberikan perlakuan mendapatkan rata-rata sebesar 38,06. Hasil penelitian menunjukkan bahwa terdapat perbedaan nilai kecerdasan interpersonal anak sebelum dan setelah diberikan perlakuan bermain peran. Hal ini merujuk pada nilai $\mathrm{T}$ hitung yang diperoleh yaitu sebesar 120 dan T tabel sebesar 25 maka diperoleh hasil T hitung (120) $>$ nilai $\mathrm{T}$ tabel sebesar (25) maka $\mathrm{H}_{1}$ diterima dan $\mathrm{H}_{0}$ ditolak artinya ada pengaruh bermain peran terhadap kecerdasan interpersonal pada anak, sedangkan nilai $Z$ hitung yang diperoleh yaitu 16,7 dan $Z$ tabel 1,645 maka diperoleh hasil nilai $Z$ hitung $(16,7)>$ nilai $Z$ tabel $(1,645)$ maka $\mathrm{H}_{1}$ diterima dan $\mathrm{H}_{0}$ ditolak yang artinya ada pengaruh bermain peran terhadap kecerdasan interpersonal pada anak.
\end{abstract}

Kata Kunci: Bermain Peran, Kecerdasan Interpersonal dan Anak Usia Dini 


\section{PENDAHULUAN}

Setiap anak memiliki tingkat kecerdasan yang berbeda-beda. Mengacu kepada teori Garder (2003), ia mengemukakan bahwa pada dasarnya kecerdasaran pada anak terbagi atas tujuh komponen kecerdasan yang dapat dikembangkan, yakni kecerdasan linguistik verbal, kecerdasan logika matematika, kecerdasan interpesonal, kecerdasan intrapersonal, kecerdasan kinestetik, kecerdasan visual spasial, dan kecerdasan ritmik musikal. Kecerdasan ini dapat dikembangkan melalui berbagai stimulasi yang diperoleh anak dari orang tua, guru maupun orang terdekat anak.

Kecerdasan interpesonal merupakan kemampuan yang dimiliki oleh anak dalam hal merespon orang-orang yang ada disekitarnya dengan positif sehingga interaksi dapat berjalan dengan baik dan efektif. Kecerdasan interpersonal terdiri atas beberapa aspek penting, yakni empati, berkomunikasi, bersikap ramah, dan bekerja sama. Kecerdasan ini, dapat dikembangkan salah satunya melalui pemberian stimulasi yang tepat sesuai dengan kebutuhan anak.

Masalah pengembangan kecerdasan interpersonal belum menjadi perhatian bagi banyak orang tua dan guru karena mereka menganggap kecerdasan interpersonal kurang penting.Mereka umumnya beranggapan bahwa anak yang dinilai pandai atau cerdas adalah anak yang memiliki kemampuan lebih baik di bidang akademik seperti kemampuan membaca, menulis, dan berhitung.Kemampuan akademik ini lebih diutamakan karena menjadi syarat untuk dapat melanjutkan kejenjang pendidikan selanjutnya yakni Sekolah Dasar. Anak yang akan memasuki Sekolah Dasar harus memiliki kemampuan membaca, menulis, dan berhitung. Syarat seperti inimembuat kecerdasan interpersonal belum menjadi perhatian untuk dikembangkan pada proses pendidikan khususnya pada Pendidikan Anak Usia Dini.Orang tua maupun guru lebih fokus kepada kecerdasan atau kemampuan akademik anak.

Berdasarkan observasi awal pada tanggal 2-4 Januari 2017, proses pembelajaran yang berlangsung di Taman Kanak-Kanak Buah Hati Makassar cenderung dominan masih bersifat individual. Proses pembelajaran yang bersifat interaktif (kelompok) kurang begitu diberikan pada Taman Kanak-Kanak Buah Hati Makassar. Adapun jika guru memberikan kegiatan yang bersifat interaktif (kelompok) kepada anak didiknya hanya sebatas seperti pemberian kegiatan 
bermain berlari secara paralel membawa sebuah benda (estafet). Proses pembelajaran yang terjadi pada Taman Kanak-Kanak Buah Hati Makassar didominasi oleh pemberian kegiatan pembelajaran yang bersifat individual seperti latihan menulis, latihan pengenalan huruf, kolase, latihan mewarnai, meronce dan beberapa kegiatan lain yang bersifat individual. Hal tersebut disebabkan karena adanya tuntutan dari para orang tua anak didik Taman KanakKanak Buah Hati Makassar bahwa ketika anak mereka selesai melakukan jenjang pendidikan pada Taman Kanak-Kanak tersebut diharapkan mampu mengenal huruf serta membaca agar lebih mudah diterima pada jenjang pendidikan berikutnya yakni Sekolah Dasar.

Salah satu kegiatan bermain yang dapat menstimulasi kecerdasan interpersonal anak ialah kegiatan bermain peran.Bermain peran merupakan suatu kegiatan bermain yang dilakukan oleh sekolompok anak. Melalui kegiatan bermain peran, anak akan banyak berinteraksi dengan oran lain, banyak berimajinasi, berkomunikasi, dan bekerja sama dengan orang lain. Menurut Madyawati (2016) bermain peran sama halnya dengan bermain purapura, anak berpura-pura menjadi seseorang dan menempatkan dirinya dalam pengalaman menjadi orang tersebut. Menghidupkan kembali sebuah adegan dapat membantu anak menghargai perasaan orang lain sehingga dapat membantu mengembangkan rasa empatinya. Bermain peran akan lebih menyenangkan jika di lakukan bersama dengan teman sebayanya, karena anak dapat belajar berkumonikasi, bergiliran, belajar berbagi peralatan atau alat permainan bersama. Sehingga, bermain peran dapat di jadikan sebagai salah satu stimulasi dalam pengembangan kecerdasan interpesonal anak. Berdasarkan latar belakang masalah diatas, maka rumusan masalah dalam penelitian ini adalah sebagai berikut (1) Bagaimana gambaran kecerdasan interpersonal anak pada Taman Kanak-Kanak Buah Hati Makassar sebelum dan setelah diberikan perlakuan bermain peran? (2) Apakah terdapat pengaruh bermain peran terhadap kecerdasan interpersonal pada anak?

\section{KAJIAN TEORETIK}

\section{Pengertian Bermain Peran (Role Play)}

Bermain adalah suatu kegiatan yang lazim dilakukan oleh anak.Tiap anak melewati fase perkembangannya melalui kegiatan bermain.Bermain merupakan dunia anak dan setiap anak senang jika melakukan kegiatan ini.Salah satu kegiatan bermain yang sering di lakukan oleh anak ialah bermain peran. Menurut Mulyasa (2012), bermain peran dalam pendidikan 
anak usia dini merupakan usaha untuk memecahkan masalah melalui peragaan yang dilakukan sendiri atau dengan sekelompok anak. Untuk kepentingan tersebut, sejumlah anak bertindak sebagai pemeran dan yang lainnya sebagai pengamat. Melalui bermain peran, anakanak berinteraksi dengan orang lain yang juga membawakan peran tertentu sesuai dengan tema yang dipilih.

Berdasarkan beberapa pendapat diatas, dapat disimpulkan bahwa bermain peran merupakan salah satu permainan yang dilakukan dengan khayalan atau pura-pura untuk memainkan suatu peran tertentu didalam masyarakat serta memungkinkan anak untuk mempelajari peran-peran sosial dalam persiapan mereka berpartisipasi dengan matang dilingkungan masyarakat.

Bermain peran tentunya memiliki kelemahan dan kelebihan tersendiri jika dibandingkan dengan kegiatan bermain yang lainnya. Menurut Shoimin (2014), kelebihan dari bermain peran ialah, 1) melalui kegiatan ini, anak dapat diajarkan untuk mengambil keputusan dan berekspresi secara utuh, 2) Bermain peran merupakan permainan yang mudah dan dapat di gunakan dalam situasi dan waktu yang berbeda, 3) guru dapat mengevaluasi pengalaman anak melalui pengamatan pada saat melakukan permainan, 4) berkesan dengan kuat dan tahan lama dalam ingatan anak, 5) sangat menarik bagi anak sehingga memungkinkan kelas menjadi dinamis dan penuh antusias, 6) membangkitkan gairah dan semangat optimisme dalam diri anak serta menumbuhkan rasa kebersamaan dan kesetiakawanan sosial yang tinggi, 7) dapat menghayati peristiwa yang berlangsung dengan mudah dan dapat memetik butir-butir hikmah yang terkandung didalamnya dengan penghayatan anak sendiri, 8) dimungkinkan dapat meningkatkan kemampuan profesionalisme anak, dan dapat menumbuhkan / membuka kesempatan bagi lapangan kerja.

Kelemahan dari bermain peran menurut Shoimin (2014) ialah, 1) kegiatan ini membutuhkan waktu yang cukup lama, 2) memerlukan kreativitas dan daya kreasi yang tinggi, 3) kebanyakan anak yang ditunjuk sebagai pemeran merasa malu untuk memainkan peran mereka, 4) apabila pelaksanaan kegiatan ini mengalami kegagalan, bukan saja dapat memberi kesan kurang baik, tetapi sekaligus berarti tujuan pengajaran tidak tercapai, 5) tidak semua materi pelajaran dapat disajikan melalui kegiatan ini.

\section{Kecerdasan Interpersonal}




\section{a. Pengertian Kecerdasan Interpesonal}

Teori kecerdasan yang dikembangkan oleh Gardner dikenal dengan istilah multiple intelligences atau MI. Gardner (2003) meyakini bahwa kecerdasan pada umunya dapat dibagibagi lagi atau dengan kata lain kecerdasan dapat dimajemukkan. Setiap individu pada umunya terlahirkan dengan profil kecerdasan yang berbeda-beda antara satu dengan yang lainnya, yang pada akhirnya akan membuat individu tersebut berbeda. Mereka memiliki kecerdasan tertentu dengan kadar yang tertentu pula. Gardner mengemukakan bahwa kecerdasan yang dapat dimajemukkan tersebut, terbagi atas tujuh jenis, yakni kecerdasan linguistik, kecerdasan logika-matematika, kecerdasan ruang, kecerdasan musik, kecerdasan gerakan-badan, kecerdasan antarpribadi (interpesonal), dan kecerdasan intra pribadi (intrapersonal)”. Ketujuh jenis kecerdasan tersebut tidak akan diuraikan secara keseluruhan, akan tetapi hanya akan berfokus pada kecerdasan interpersonal karena menjadi fokus dalam kajian ini.

Menurut Bachtiar (2015), kecerdasan interpersonal merupakan kemampuan yang dimiliki oleh anak untuk memahami dan merespon keinginan serta perasaan orang lain dengan baik sehingga interaksi kerjasama dan komunikasi bisa berjalan baik dan efektif. Hal ini sejalan dengan yang dikemukakan oleh Sujiono dkk (2005)kecerdasan interpesonal merupakan kemampuan seseorang dalam hal berkomunikasi dengan orang lain. Hal ini mengacu kepada keterampilan seseorang dalam hal membaca, berkomunikasi, dan berinteraksi dengan orang lain.

Berdasarkan dari beberapa definisi diatas mengenai pengertian dari kecerdasan interpesonal, maka dapat disimpulkan bahwa kecerdasan interpesonal merupakan kemampuan anak untuk memahami dan merespon keinginan serta perasaan orang lain sehingga komunikasi dapat berjalan denganbaik.. Kecerdasan interpersonal terdiri atas beberapa aspek penting, yakni empati, komunikasi, bersikap ramah, dan kerja sama.

\section{b. Karakteristik kecerdasan interpesonal pada Anak Usia Dini}

Lwin (2008) mengemukakan secara sederhana anak yang mempunyai kecerdasan interpesonal tinggi, memiliki karakteristik seperti, anak cenderung suka berteman dan berkenalan dengan orang lain, senang berada disekitar orang lain, anak memiliki rasa ingin tahu mengenai orang lain dan ramah terhadap orang asing, cenderung senang menggunakan mainannya dengan teman-temannya, mengalah kepada anak lain, mengerti bagaimana 
menunggu gilirannya selama bermain, aktif dalam permainan kelompok, suka mengarahkan temannya, dan kompak bermain dengan teman-temannya,

Karakteristik anak yang memiliki kecerdasan interpersonal yang tinggi cenderung suka dan mudah bergaul dengan orang-orang yang ada disekitarnya.Anak yang memiliki tingkat kecerdasan interpersonal yang tinggi cenderung suka dengan dunia sosial atau dunia bermasyarakat.Mereka cenderung dapat dengan mudah merespons secara positif orang-orang yang ada disekitar mereka.

\section{METODOLOGI}

Pendekatanpenelitian bersifat kuantitatifdanJenis penelitian pada penelitian ini ialah eksperimen sederhana atau terkadang lebih dikenal dengan istilah pre-experimental. Menurut Sugiyono (1999) desain one group pretest-posttest design merupakan desain penelitian yang terdapat pretest sebelum diberikan perlakuan dan posttest setelah diberikan perlakuan. Desain ini dapat digambarkan sebagai berikut :

$$
\mathrm{O}_{1} \times \mathrm{O}_{2}
$$

Gambar 1 Desain Penelitian

Keterangan :

O1: Nilai Pretest (Kecerdasan interpersonal anak sebelum dilaksanakan kegiatan bermain peran)

$\mathrm{X}$ : Perlakuan menggunakan kegiatan bermain peran

O2 : Nilai Posttes (Kecerdasan interpersonal anak setelah dilaksanakan kegiatan bermain peran).

Tabel 1 Kisi-Kisi Instrumen Kecerdasan Interpersonal

\begin{tabular}{|c|l|c|c|}
\hline Variabel & \multicolumn{1}{|c|}{ SubVariabel } & Nomor Butir & Jumlah \\
\hline \multirow{2}{*}{$\begin{array}{c}\text { Kecerdasan } \\
\text { Interpersonal }\end{array}$} & Menjalin Kontak & $1,2,3,4$ & 4 \\
\cline { 2 - 4 } & Empati & 5,6 & 2 \\
\cline { 2 - 4 } & Komunikasi & $7,8,9$ & 3 \\
\cline { 2 - 4 } & Kerja Sama & 10,11 & 2 \\
\hline
\end{tabular}




\begin{tabular}{|l|l|c|c|}
\hline & Bersikap Ramah & $12,13,14,15$ & 4 \\
\hline
\end{tabular}

Data tentang kecerdasan interpersonal di kumpulkan dengan menggunakan pengamatan skala Likert yang berbentuk skala sikap. Widoyoko (2012) menjelaskan bahwa skala Likert ialah skala yang dapat di pergunakan untuk mengukur sikap, pendapat, dan persepsi seseorang atau sekelompok orang tentang suatu gejala atau fenomena pendidikan.Ada dua bentuk pertanyaan yang menggunakan skala Likert yaitu bentuk pertanyaan positif untuk mengukur sikap positif, dan bentuk pertanyaan negatif untuk mengukur sikap negatif.

\section{HASIL DAN PEMBAHASAN}

Berikut ini akan diuraikan secara lebih jelas mengenai hasil pengamatan kecerdasan interpersonal anak pada Taman Kanak-Kanak Buah Hati Kota Makassar sebelum diberikan perlakuan bermain peran :

Tabel 1.Pretest Kecerdasan Interpersonal Anak

\begin{tabular}{|c|c|c|c|}
\hline No. & Uraian & Jumlah & Persentase \\
\hline \multirow{3}{*}{1} & Sering & 0 & $0 \%$ \\
\hline & Kadang-Kadang & 5 & $33 \%$ \\
\hline & Tidak Pernah & 10 & $67 \%$ \\
\hline \multirow{3}{*}{2} & Sering & 0 & $0 \%$ \\
\hline & Kadang-Kadang & 1 & $7 \%$ \\
\hline & Tidak Pernah & 14 & $93 \%$ \\
\hline \multirow{3}{*}{3} & Sering & 0 & $0 \%$ \\
\hline & Kadang-Kadang & 9 & $60 \%$ \\
\hline & Tidak Pernah & 6 & $40 \%$ \\
\hline \multirow{3}{*}{4} & Sering & 0 & $0 \%$ \\
\hline & Kadang-Kadang & 11 & $73 \%$ \\
\hline & Tidak Pernah & 4 & $27 \%$ \\
\hline \multirow{3}{*}{5} & Sering & 0 & $0 \%$ \\
\hline & Kadang-Kadang & 2 & $13 \%$ \\
\hline & Tidak Pernah & 13 & $87 \%$ \\
\hline \multirow{3}{*}{6} & Sering & 0 & $0 \%$ \\
\hline & Kadang-Kadang & 6 & $40 \%$ \\
\hline & Tidak Pernah & 9 & $60 \%$ \\
\hline \multirow{3}{*}{7} & Sering & 0 & $0 \%$ \\
\hline & Kadang-Kadang & 2 & $13 \%$ \\
\hline & Tidak Pernah & 13 & $87 \%$ \\
\hline
\end{tabular}




\begin{tabular}{|c|c|c|c|}
\hline \multirow{3}{*}{8} & Sering & 0 & $0 \%$ \\
\hline & Kadang-Kadang & 4 & $27 \%$ \\
\hline & Tidak Pernah & 11 & $73 \%$ \\
\hline \multirow{3}{*}{9} & Sering & 0 & $0 \%$ \\
\hline & Kadang-Kadang & 14 & $93 \%$ \\
\hline & Tidak Pernah & 1 & $7 \%$ \\
\hline \multirow{3}{*}{10} & Sering & 0 & $0 \%$ \\
\hline & Kadang-Kadang & 13 & $87 \%$ \\
\hline & Tidak Pernah & 2 & $13 \%$ \\
\hline \multirow{3}{*}{11} & Sering & 0 & $0 \%$ \\
\hline & Kadang-Kadang & 11 & $73 \%$ \\
\hline & Tidak Pernah & 4 & $27 \%$ \\
\hline \multirow{3}{*}{12} & Sering & 0 & $0 \%$ \\
\hline & Kadang-Kadang & 0 & $0 \%$ \\
\hline & Tidak Pernah & 15 & $100 \%$ \\
\hline \multirow{3}{*}{13} & Sering & 0 & $0 \%$ \\
\hline & Kadang-Kadang & 12 & $80 \%$ \\
\hline & Tidak Pernah & 3 & $20 \%$ \\
\hline \multirow{3}{*}{14} & Sering & 0 & $0 \%$ \\
\hline & Kadang-Kadang & 14 & $93 \%$ \\
\hline & Tidak Pernah & 1 & $7 \%$ \\
\hline \multirow{3}{*}{15} & Sering & 0 & $0 \%$ \\
\hline & Kadang-Kadang & 10 & $67 \%$ \\
\hline & Tidak Pernah & 5 & $33 \%$ \\
\hline
\end{tabular}

Berdasarkan tabel pretest diatas dapat diketahui bahwa dari keseluruhan butir instrumen (15 pernyataan) menunjukkan bahwa secara keseluruhan tidak terdapat satupun anak yang menunjukkan sikap dengan kategori "sering" karena persetase yang didapatkan ialah $0 \%$, dan hanya terdapat beberapa persentase tinggi pada butir instrumen dengan kategori "kadang-kadang" yakni persentase tertinggi ialah $93 \%$ yang terdapat pada butir instrumen no. 9 dan no.14.

Kemudian, dari hasil pretest tersebut, maka dilakukan analisis deskripstif untuk mengetahui nilai rata-rata (mean), nilai maksimal dan nilai minimal. Untuk lebih jelasnya dapat dilihat pada tabel berikut :

Tabel 2. Data Perhitungan Deskriptif Hasil Pretest

\begin{tabular}{|c|c|}
\hline Data Perhitungan & Data Pretest \\
\hline $\mathrm{N}$ & 15 \\
\hline
\end{tabular}




\begin{tabular}{lc}
\hline Rata-rata (mean) & 22,6 \\
\hline Nilai Minimal & 20 \\
\hline Nilai Maksimal & 27 \\
\hline
\end{tabular}

Berdasarkan tabel diatas dapat diketahui bahwa data pretest menunjukkan skor maksimal sebesar 27 dan skor minimal sebesar 20 dengan nilai rata-rata (mean) sebesar 22,6.

Berikut ini akan diuraikan secara lebih jelas mengenai hasil pengamatan kecerdasan interpersonal anak pada Taman Kanak-Kanak Buah Hati Kota Makassar setelah diberikan perlakuan bermain peran:

Tabel 3.Posttest Kecerdasan Interpersonal Anak

\begin{tabular}{|c|c|c|c|}
\hline No. & Uraian & Jumlah & Persentase \\
\hline \multirow{3}{*}{1} & Sering & 3 & $20 \%$ \\
\hline & Kadang-Kadang & 12 & $80 \%$ \\
\hline & Tidak Pernah & 0 & $0 \%$ \\
\hline \multirow{3}{*}{2} & Sering & 2 & $13 \%$ \\
\hline & Kadang-Kadang & 13 & $87 \%$ \\
\hline & Tidak Pernah & 0 & $0 \%$ \\
\hline \multirow{3}{*}{3} & Sering & 10 & $67 \%$ \\
\hline & Kadang-Kadang & 5 & $33 \%$ \\
\hline & Tidak Pernah & 0 & $0 \%$ \\
\hline \multirow{3}{*}{4} & Sering & 12 & $80 \%$ \\
\hline & Kadang-Kadang & 3 & $20 \%$ \\
\hline & Tidak Pernah & 0 & $0 \%$ \\
\hline \multirow{3}{*}{5} & Sering & 2 & $13 \%$ \\
\hline & Kadang-Kadang & 13 & $87 \%$ \\
\hline & Tidak Pernah & 0 & $0 \%$ \\
\hline \multirow{3}{*}{6} & Sering & 6 & $40 \%$ \\
\hline & Kadang-Kadang & 9 & $60 \%$ \\
\hline & Tidak Pernah & 0 & $0 \%$ \\
\hline \multirow{3}{*}{7} & Sering & 2 & $13 \%$ \\
\hline & Kadang-Kadang & 13 & $87 \%$ \\
\hline & Tidak Pernah & 0 & $0 \%$ \\
\hline \multirow{3}{*}{8} & Sering & 9 & $60 \%$ \\
\hline & Kadang-Kadang & 6 & $40 \%$ \\
\hline & Tidak Pernah & 0 & $0 \%$ \\
\hline
\end{tabular}




\begin{tabular}{|c|c|c|c|}
\hline \multirow{3}{*}{9} & Sering & 15 & $100 \%$ \\
\hline & Kadang-Kadang & 0 & $0 \%$ \\
\hline & Tidak Pernah & 0 & $0 \%$ \\
\hline \multirow{3}{*}{10} & Sering & 10 & $67 \%$ \\
\hline & Kadang-Kadang & 5 & $33 \%$ \\
\hline & Tidak Pernah & 0 & $0 \%$ \\
\hline \multirow{3}{*}{11} & Sering & 12 & $80 \%$ \\
\hline & Kadang-Kadang & 3 & $20 \%$ \\
\hline & Tidak Pernah & 0 & $0 \%$ \\
\hline \multirow{3}{*}{12} & Sering & 1 & $7 \%$ \\
\hline & Kadang-Kadang & 14 & $93 \%$ \\
\hline & Tidak Pernah & 0 & $0 \%$ \\
\hline \multirow{3}{*}{13} & Sering & 12 & $80 \%$ \\
\hline & Kadang-Kadang & 3 & $20 \%$ \\
\hline & Tidak Pernah & 0 & $0 \%$ \\
\hline \multirow{3}{*}{14} & Sering & 13 & $87 \%$ \\
\hline & Kadang-Kadang & 2 & $13 \%$ \\
\hline & Tidak Pernah & 0 & $0 \%$ \\
\hline \multirow{3}{*}{15} & Sering & 12 & $80 \%$ \\
\hline & Kadang-Kadang & 3 & $20 \%$ \\
\hline & Tidak Pernah & 0 & $0 \%$ \\
\hline
\end{tabular}

Berdasarkan tabel posttest diatas dapat diketahui bahwa dari keseluruhan butir instrumen (15 pernyataan) menunjukkan bahwa secara keseluruhan tidak terdapat satupun anak yang menunjukkan sikap dengan kategori "tidak pernah" karena persetase yang didapatkan ialah $0 \%$, dan terdapat beberapa persentase tinggi pada butir instrumen dengan kategori "sering" yakni persentase tertinggi ialah $100 \%$ terdapat pada butir instrumen no. 9 dan $87 \%$ pada butir instrumen no.14. Hal ini secara tidak langsung dapat menunjukkan bahwa terdapat kemajuan sikap pada anak sebelum dan setelah diberikan perlakuan bermain peran.

Kemudian, dari hasil posttest tersebut, maka dilakukan analisis deskripstif untuk mengetahui nilai rata-rata (mean), nilai maksimal dan nilai minimal. Untuk lebih jelasnya dapat dilihat pada tabel berikut :

Tabel 4 Data Perhitungan Deskriptif Hasil Posttest

\begin{tabular}{cc}
\hline Data Perhitungan & Data Pretest \\
\hline $\mathrm{N}$ & 15 \\
\hline
\end{tabular}




\begin{tabular}{cc}
\hline Rata-rata (mean) & 38,06 \\
\hline Nilai Minimal & 37 \\
\hline Nilai Maksimal & 40
\end{tabular}

Berdasarkan tabel diatas dapat diketahui bahwa data posttest menunjukkan skor maksimal sebesar 40 dan skor minimal sebesar 37 dengan nilai rata-rata (mean) sebesar 38,06.

Hasil penelitian yang diperoleh berdasarkan data dari hasil observasi awal dan akhir, maka dapat diketahui bahwa pengaruh penerapan metode bermain peran terhadap kecerdasan interpersonal anak setelah dilakukan uji hipotesis dengan analisis uji Wilcoxon. Adapun langkah-langkah yang dilakukan adalah sebagai berikut :

a. Mengetahui nilai skor $\mathrm{O}_{1}$ (sebelum diberi perlakuan) dan nilai $\mathrm{O}_{2}$ (setelah diberi perlakuan)

b. Mengetahui selisih antara nilai $\mathrm{O}_{1}$ dan $\mathrm{O}_{2}$

c. Membuat ranking dari keseluruhan jumlah anak dengan cara mengurutkan nilai dari yang tertinggi sampai yang terendah, kemudian dari atas diberi angka yang menunjukkan ranking mulai dari angka 1,2,3 dst. Nilai yang sama harus diberi ranking yang sama pula, yaitu dengan membagi bilangan nilai ranking secara adil pada semua pemiliki nilai yang sama. Bubuhkan pada setiap ranking tanda (+ atau -).

d. Untuk menetapkan nilai $\mathrm{T}$, nilai tanda yang terkecil dijumlahkan dari kedua kelompok ranking yang memiliki tanda yang sama, dan $\mathrm{N}$ didapatkan dari jumlah sampe yang diteliti.

e. Kemudian dilakukan perbandingan antara nilai $\mathrm{T}$ hitung yang diperoleh dengan nilai $\mathrm{T}$ pada tabel uji Wilcoxon.

Untuk lebih jelasnya hasil data yang diperoleh dapat dilihat pada tabel berikut :

Tabel 5. Pengaruh Bermain Peran Terhadap Kecerdasan Interpersonal Pada Anak

\begin{tabular}{|c|c|c|c|c|c|c|c|}
\hline \multirow{2}{*}{ No } & \multirow{2}{*}{$\begin{array}{l}\text { Nama } \\
\text { Anak }\end{array}$} & \multicolumn{2}{|c|}{ Nilai statistik kemampuan sains } & \multirow{2}{*}{$\begin{array}{l}\text { Selisih } \\
\text { Nilai } \\
\left(\mathrm{O}_{1}-\mathrm{O}_{2}\right)\end{array}$} & \multirow{2}{*}{ Ranking } & \multicolumn{2}{|c|}{$\begin{array}{c}\text { Tanda } \\
\text { Ranking }\end{array}$} \\
\hline & & Sebelum $\left(\mathrm{O}_{1}\right)$ & Sesudah $\left(\mathrm{O}_{2}\right)$ & & & + & - \\
\hline 1. & Renal & 27 & 40 & 13 & 15 & 15 & \\
\hline 2. & Sultan & 23 & 38 & 15 & 10 & 10 & \\
\hline 3. & $\mathrm{CL}$ & 20 & 38 & 18 & 1,5 & 1,5 & \\
\hline 4. & AM & 21 & 39 & 18 & 1,5 & 1,5 & \\
\hline 5. & $\mathrm{MC}$ & 22 & 37 & 15 & 10 & 10 & \\
\hline 6. & AR & 23 & 38 & 15 & 10 & 10 & \\
\hline
\end{tabular}




\begin{tabular}{|c|c|c|c|c|c|c|}
\hline 7 & SL & 23 & 38 & 15 & 10 & 10 \\
\hline 8. & AR & 23 & 38 & 15 & 10 & 10 \\
\hline 9. & RN & 21 & 37 & 16 & 4 & 4 \\
\hline 10. & JB & 20 & 36 & 16 & 4 & 4 \\
\hline 11. & AS & 25 & 40 & 15 & 10 & 10 \\
\hline 12. & AW & 23 & 38 & 15 & 10 & 10 \\
\hline 13. & $\mathrm{AB}$ & 25 & 40 & 15 & 10 & 10 \\
\hline 14. & TP & 21 & 37 & 16 & 4 & 4 \\
\hline 15. & DT & 22 & 37 & 15 & 10 & 10 \\
\hline & Jumlah & 339 & 571 & & \multirow{2}{*}{\multicolumn{2}{|c|}{ Nilai $\mathrm{T}: 12$}} \\
\hline & Rata2 & 22,6 & 38,06 & & & \\
\hline
\end{tabular}

Berdasarkan tabel 5 mengenai data kecerdasan interpersonal anak sebelum dan setelah diberi perlakuan bermain peran menunjukkan ranking bertanda positif $(+)=120$, dan jumlah ranking bertanda negatif $(-)=0$, maka T merupakan 120. Dalam pengambilan keputusan, jika $\mathrm{T}$ hitung $<\mathrm{T}$ tabel maka Ho diterima $\mathrm{H}_{1}$ ditolak yang artinya tidak ada pengaruh bermain peran terhadap kecerdasan intepersonal pada anak di Kelas B di Taman Kanak-Kanak Buah Hati Kota Makassar, dan sebaliknya jika $\mathrm{T}$ hitung $>\mathrm{T}$ tabel maka Ho ditolak dan $\mathrm{H}_{1}$ diterima yang artinya terdapat pengaruh bermain peran terhadap kecerdasan interpersonal pada anak Kelas B di Taman Kanak-Kanak Buah Hati Kota Makassar.

$\mathrm{Z}$ hitung $<\mathrm{Z}$ tabel maka Ho diterima dan $\mathrm{H}_{1}$ ditolak yang artinya tidak ada pengaruh bermain peran terhadap kecerdasan interpersonal pada anak Kelas B Di Taman Kanak-Kanak Buah Hati Kota Makassar, dan sebaliknya jika Z hitung $>\mathrm{Z}$ tabel maka Ho ditolak dan $\mathrm{H}_{1}$ diterima yang artinya terdapat pengaruh bermain peran terhadap kecerdasan interpersonal pada anak Kelas B Di Taman Kanak-Kanak Buah Hati Kota Makassar.

Adapun nilai T hitung yang diperoleh yakni 120 , dan T tabel 25 maka diperoleh hasil $\mathrm{T}$ hitung (120) $>\mathrm{T}$ tabel (25) maka $\mathrm{H}_{1}$ diterima dan Ho ditolak yang artinya terdapat pengaruh bermain peran terhadap kecerdasan interpersonal pada anak, sedangkan nilai $Z$ hitung $(16,7)$ dan $\mathrm{Z}$ tabel $(1,645)$ maka diperoleh hasil $\mathrm{Z}$ hitung $(16,7)>\mathrm{Z}$ tabel $(1,645)$ maka $\mathrm{H}_{1}$ diterima dan Ho ditolak yang artinya terdapat pengaruh bermain peran terhadap kecerdasan interpersonal pada anak. Hasil uji menunjukkan bahwa terdapat perbedaan nilai pada kecerdasan interpersonal anak sebelum dan setelah mendapat perlakuan kegiatan bermain peran. 


\section{PEMBAHASAN}

Berdasarkan hasil analisis uji Wilcoxon, menunjukkan bahwa terdapat perbedaan yang signifikan antara kecerdasan interpersonal anak sebelum dan setelah diberi perlakuan bermain peran.Perbedaan yang dimaksud ialah rata-rata skor kecerdasan interpersonal anak mengalami peningkatan setelah diberikan perlakuan kegiatan bermain peran dibandingkan ketika sebelum anak diberikan perlakuan kegiatan bermain peran.

Hal ini disebabkan karena kegiatan bermain peran mengajak anak untuk berinteraksi dengan teman sebayanya, sehingga secara tidak langsung dapat mengasah kecerdasan interpersonal pada anak.Sebagaimana dengan pendapat yang dikemukakan oleh salah satu ahli yakni Delaney (2010) kunci untuk membantu anak-anak dalam mengembangkan kecerdasan interpersonalnya ialah dengan memberikan anak kesempatan untuk berinteraksi dengan lingkungan sekitarnya, misalnya dengan bermain. Melalui kegiatan bermain, anak akan banyak berinteraksi dengan orang lain sehingga secara tidak langsung dapat menstimulasi kecerdasan interpersonal pada anak.

Kegiatan bermain yang dapat mengasah kecerdasan interpersonal anak ialah bermain peran. Melalui kegiatan bermain peran, anak secara tidak langsung akan diajak untuk berinteraksi dengan teman sebayanya, anak akan banyak berkomunikasi dengan teman sebayanya ketika memainkan peran yang diberikan oleh guru sehingga secara tidak langsung dapat menstimulasi kecerdasan interpersonal pada anak itu sendiri.

Pada kegiatan bermain peran kali ini, anak diberi kesempatan untuk memainkan peran dilingkungan sekolah dimana terdapat seorang anak yang berperan sebagai seorang ayah yang menjemput anaknya pulang dari sekolah dan ada pula yang berperan menjadi seorang ibu yang menunggu ayah dan anaknya tiba dirumah.Melalui kegiatan bermain peran ini, anak secara tidak langsung diberikan pengalaman untuk berinteraksi dengan teman sebayanya, ikut aktif dalam permainan kelompok, dan secara tidak langsung pula anak diajarkan untuk menghargai orang tua yang ketika pulang sekolah harus menyalimi ibu ataupun ayah yang menunggu dirumah.

Kegiatan bermain peran selanjutnya yang dilakukan ialah kegiatan bermain peran dengan caramemerankan peran menjadi seorang guru dan beberapa orang murid yang mendengarkan serta memperhatikan guru yang sedang menjelaskan didepan kelas. Ketika 
anak memainkan peran ini, anak secara tidak langsung diperkenalkan bagaimana dunia sosial, yakni salah satunya ialah dunia sekolah.Selain dari pada itu, anak mendapatkan pengalaman bagaimana ketika seseorang menjadi seorang guru yang mampu memberikan penjelasan didepan kelas.Melalui kegiatan bermain peran yang dilakukan oleh anak ini, secara tidak langsung anak diberikan stimulasi agar mampu berani tampil didepan umum (yakni memberikan penjelasan didepan kelas), anak dapat ikut aktif dalam permainan secara berkelompok sehingga secara tidak langsung terjalin interaksi antara anak yang satu dengan anak yang lainnya.Melalui kegiatan tersebut secara tidak langsung anak diberikan stimulasi demi pengembangan kecerdasan interpersonalnya karena anak diberikan kesempatan untuk banyak berinteraksi dengan teman-teman sebayanya.

Dari penjelasan diatas dapat dikatakan bahwa kegiatan bermain peran merupakan salah satu stimulasi yang baik dalam hal pengembangan kecerdasan interpersonal pada anak.Mengacu kepada teori yang dikemukakan oleh salah satu ahli yakni Budimanjaya (2015), memaparkan bahwa bermain peran merupakan pembelajaran yang menekankan pada permainan secara berpura-pura dengan memerankan peran tokoh tertentu. Melalui bermain peran anak akan banyak berinteraksi dengan teman sebayanya sehingga dapat dijadikan salah satu stimulasi untuk mengembangkan kecerdasan interpersonal pada anak karena permainan ini di mainkan secara berkelompok dan membutuhkan adanya interaksi antara pemain satu dengan pemain yang lainnya. Selain dari pada itu, pendapat yang tidak jauh berbeda dikemukakan pula oleh Montolalu, dkk (2005) yakni salah satu manfaat dari kegiatan bermain peran ialah dapat mengembangkan kemampuan anak dalam bersosialisasi dan berkomunikasi serta secara tidak langsung dapat menstimulasi dalam menggali perasaan anak.Dengan adanya pengembangan kemampuan anak dalam bersosialisasi dan berkomunikasi, secara tidak langsung dapat memberikan stimulasi pada kecerdasan interpersonal anak itu sendiri. Seperti yang telah dipaparkan pada bagian Tinjauan Pustaka, yakni salah satu ahli yaitu Suyadi (2010) mengemukakan bahwa kecerdasan interpersonal merupakan kemampuan yang dimiliki oleh seorang anak dalam hal berhubungan dan berinteraksi dengan orang lain. Kemampuan yang dimiliki oleh anak dalam hal kepekaan hati yang tinggi. Dimana anak yang memiliki kecerdasan interpersonal yang tinggi, mereka dapat memahami dan mengerti orang lain. Sehingga jika dikaitkan antara teori kecerdasan interpersonal yang dikemukakan oleh Suyadi 
dan teori bermain peran yang dikemukakan oleh Montolalu, memiliki keterkaitan antara satu dengan yang lain. Bahwa dimana kecerdasan interpersonal merupakan kemampuan yang dimiliki oleh seorang anak dalam hal berhubungan dan berinteraksi dengan orang lain, dan disisi lain Montolalu memaparkan bahwa salah satu manfaat bermain peran ialah dapat mengembangkan kemampuan anak dalam bersosialisasi dan berkomunikasi, sehingga secara tidak langsung dapat menstimulasi kecerdasan interpersonal pada anak.

Kegiatan bermain peran merupakan salah satu stimulasi yang baik dalam hal pengembangan kecerdasan interpersonal pada anak, sehingga pendidik sebaiknya memberikan banyak kesempatan kepada anak didiknya untuk melakukan kegiatan bermain peran dalam proses pembelajaran yang diberikan sehingga anak didik mendapat lebih banyak kesempatan untuk berinteraksi dan berkomunikasi serta mengenal dunia-dunia sosial. Kecerdasan interpersonal merupakan salah satu kecerdasan yang penting dimiliki oleh seseorang sejak dini, karena pada umumnya kecerdasan interpersonal merupakan kemampuan untuk berinteraksi dengan dunia sosial. Seperti yang kita ketahui, manusia merupakan mahluk sosial yang tidak dapat bertahan hidup sendiri, sehingga kecerdasan interpersonal sangat penting dimiliki oleh seseorang sejak dini agar dapat menjalin interaksi yang baik dengan dunia sosial dikehidupan akan datang. Salah satu teori mengemukakan bahwa seseorang yang memiliki kecerdasan interpersonal yang tinggi dapat menjadi seorang pemimpin yang handal karena pada dasarnya ia mampu memahami dan menyikapi orang-orang disekitarnya dengan baik, sehingga orang yang memiliki kecerdasan interpersonal yang baik dapat dijadikan sebagai salah satu pemimpin.

\section{KESIMPULAN}

Berdasarkan dari data yang diperoleh dari hasil observasi awal dan hasil observasi akhir, yakni sebelum dan setelah diberi perlakuan maka dapat disimpulkan bahwa :

1. Berdasarkan penelitian yang telah dilakukan oleh peneliti, kecerdasan interpersonal yang ditunjukkan oleh anak sebelum mendapatkan perlakuan bermain peran masih cenderung kurang, hal tersebut ditunjukkan dengan masih terdapat beberapa persentase yang tinggi pada beberapa instrumen dengan kategori "tidak pernah". Sedangkan kecerdasan interpersonal yang ditunjukkan oleh anak setelah mendapatkan perlakuan bermain peran dapat dikategorikan tinggi atau dengan kata lain mengalami perubahan. Hal tersebut 
ditunjukkan oleh terdapatnya beberapa persentase yang tinggi pada beberapa instrumen dengan kategori "sering".

2. Berdasarkan penelitian yang telah dilakukan oleh peneliti, terdapat kesimpulan bahwa bermain peran memberikan pengaruh terhadap kecerdasan interpersonal pada anak. Hal tersebut ditandai dengan adanya perubahan sikap positif yang ditunjukkan oleh anak setelah mendapatkan perlakuan bermain peran.

\section{DAFTAR PUSTAKA}

Ansharullah. (2011). Pendidikan Islam Berbasis Kecerdasan Jamak Multiple Intelligences. Jakarta: Step Publishing.

Bachtiar, Yusri. (2015). Pengaruh Jenis Permainan dan Gaya Belajar Terhadap Kecerdasan Interpersonal.Disertasi. Jakarta: Program Pascasarjana Universitas Negeri Jakarta.

Beaty, J. J. (2013). Observasi Perkembangan Anak Usia Dini.Diterjemahkan oleh Arif Rakhman. Jakarta: Kencana.

Budimanjaya, Andi dan Alamsyah Said. (2015). 95 Strategi Mengajar Multiple Intelligences. Jakarta: Kencana

Bungin, Burhan. (2005). Metodologi Penelitian Kuantitatif. Jakarta: Kencana.

Dananjaya, Utomo. (2013). Media Pembelajaran Aktif. Bandung: Nuansa Cendekia.

Delaney, Tara. (2010). 101 Permainan dan Aktivitas anak. Yogyakarta: ANDI Yogyakarta.

Efendi, Agus. (2005). Revolusi Kecerdasan Abad 21 Kritik MI, EI, SQ, AQ \& Syccessfull Intelligence Atas IQ. Bandung: Alfabeta.

Yuriastien, Effiana, dkk. (2009). Games Theraphy Untuk Kecerdasan Bayi dan Balita. Jakarta: Wahyu Media.

Gardner, H. (2003). Kecerdasan Interpersonal. Diterjemahkan Alexander Sindoro. Batam: Interaksara.

Hartati, Sofia. (2007). How To Be A Good Teacher and To Be A Good Mother. Jakarta Selatan: Enn Media.

Husna, A. M. (2009). 100+ Permainan Tradisional Indonesia. Yogyakarta : ANDI Yogyakarta. 
Ismail, Andar. (1998). Ajarilah Mereka Melakukan.(online). https://books.google.co.id/books?id=g_D5RrSis-

$4 \mathrm{C} \&$ printsec $=$ frontcover\&dq $=$ buku + ajarlah + mereka + melakukan $\& h l=i d \& s a=X \& v e d=$ 0ahUKEwifkcL9tLDMAhVB4aYKHaWhBVkQ6AEIIjAA\#v=onepage \&q=buku\%20 ajarlah\%20mereka\%20melakukan\&f=false. Diakses pada tanggal 28 April 2016.

Lwin, May, dkk. (2008). Cara mengembangkan berbagai komponen kecerdasan.Diterjemahkan oleh Sugirin. Jakarta: PT Indeks.

Madyawati, Lilis. (2016). Strategi Pengembangan Bahasa Pada Anak. Jakarta: Prenadamedia Group.

Montolalu, dkk. (2005). Bermain dan Permainan Anak. Jakarta: Universitas Terbuka.

Mulyasa. (2012). Manajemen PAUD. Bandung: PT Remaja Rosdakarya.

Musfiroh, Tadkiroatun. (2008). Pengembangan Kecerdasan Majemuk. Jakarta: Universitas Negeri Terbuka.

Mustofa, Arif dan Muhammad Thobroni. (2011). Belajar dan Pembelajaran Pengembangan Wacana dan Praktik Pembelajaran Dalam Pembangunan Nasional.

Santoso, Soegeng. (2011). Konsep Pendidikan Anak Usia Dini Menurut Penelitinya 2. Jakarta: Universitas Negeri jakarta.

Sefrina, Andin. (2013). Deteksi Minat Bakat Anak. Yogyakarta: Media Pressindo.

Shoimin, A. (2014). 68 Model Pembelajaran Inovatif Dalam Kurikulum 2013. Yogyakarta: Ar-Ruzz Media.

Siswanto, Igrea. (2008). Mendidik Anak Dengan Permainan Kreatif. Yogyakarta: ANDI. Sugiyono. (2011). Metode Penelitian Kombinasi (Mixed Methods). Bandung: Alfabeta. . (1999). Metode Penelitian Bisnis. Bandung: Alfabeta. .(2012). Statistik Nonparaeteris.Bandung: Alfabeta.

Sujiono, Yuliani Nurani, dkk. (2005). Pembelajaran Anak Usia Dini. Jakarta: Yayasan Citra Pendidikan Indonesia.

Suparman, Atwi. (1997). Model-Model Pembelajaran Interaktif. Jakarta: STIA-LAN Press. 
Suparno, Paul. (2004). Teori Inteligensi Ganda dan Aplikasinya di Sekolah. Yogyakarta: Kanisius.

Surya, H. (2010). Rahasia Membuat Anak Cerdas Dan Manusia Unggul. Jakarta: PT Elex Media Komputindo.

Susanto, Ahmad. (2011). Perkembangan Anak Usia Dini Pengantar Dalam Berbagai Aspeknya. Jakarta: Kencana.

Suyadi. (2010). Psikologi Belajar Pendidikan Anak Usia Dini. Yogyakarta: Edagogia.

Tedjasaputra, Mayke. S. (2001). Bermain, Mainan, dan Permainan Untuk Pendidikan Anak Usia Dini. Jakarta: PT Grasindo.

Trianto. (2011). Desain Pengembangan Pembelajaran Tematik. Jakarta: Kencana.

Widoyoko, Eko Putro. (2012). Teknik Penyusunan Instrumen Penelitian. Yogyakarta: Pustaka Pelajar. 